\title{
Reviews of Books
}

Bibliographie der Hals-, Nasen- und Ohrenheilkunde, Sowie Deren Grenzgebiete. (Erster Band. Bericht für das Jahr 1922.) Berlin : Verlag von Julius Springer, 1924.

This publication represents, as it also apparently claims to be, a complete and universal list of all the published articles relative to our specialty for the year 1922. It is divided into the main headingsThroat, Nose, and Ear-with a preliminary section on general subjects connected therewith, such as anæsthetics, instruments, asthma, whooping-cough, etc. The three special sections are again subdivided under the various headings into which our work is naturally grouped.

Thus, with an excellent table of contents at the beginning and an index of authors at the end, the reader can refer, with a minimum of time and trouble, either to the works on any special subject desired or to the writings of any author whom he may wish to consult.

It is, of course, purely a publication for reference, but as such it should certainly find a place in every library of laryngology and otology.

The volume appears to have been prepared with great care, and the number of pages $(276)$ is perhaps sufficient indication of the compiler's effort to embrace fully everything published during the period concerned.

Alex. R. Tweedie.

\section{GENERAL NOTES}

\author{
Royal Society of Medicine. \\ I Wimpole Street, London, W.I.
}

Section of Laryngology-President, A. Logan Turner, M.D.; Hon. Secretaries, E. D. D. Davis, F.R.C.S., 46 Harley Street, London, W.I, and Philip Franklin, F.R.C.S., 27 Wimpole Street, London, W.I.

The first Meeting of the Section will be held on Friday, 7 th November, at 5 P.M. Patients will be shown at 4 o'clock. Members intending to exhibit cases or specimens are asked to send notice of the same to the Senior Hon. Secretary, Mr E. D. D. Davis, F.R.C.S., along with a précis stating the more important facts and drawing attention to the points upon which discussion is invited.

Section of Otology-President, J. Kerr Love, M.D.; Hon. Secretaries, T. H. Just, F.R.C.S., 16 Upper Wimpole Street, London, W.I, and F. W. Watkyn-Thomas, F.R.C.S., I4 Welbeck Street, London, W.I.

The first Meeting of the Section will be held on Saturday, 8th November, at Io A.M. Patients, specimens, etc., must be in the meeting-room before 


\section{General Notes}

9.45 o'clock, and notice of the same along with a short description of the cases must be sent to the Senior Hon. Secretary, Mr T. H. Just.

During the Session 1924-25, the Sections will meet on the following dates :-

Section of Laryngology, on Friday, $7^{\text {th }}$ November, 5th December, 6th February, 6th March, 3rd April, Ist May (Annual), and 5th June.

Section of Otology, on Saturday, 8th November, 6th December, 7th February, 7th March, 2nd May (Annual), and 6th June.

During the Session 1924-25, a series of Discussions upon subjects of general interest will be held at the Royal Society of Medicine. The Programme includes two which will be discussed by the whole Society, viz.,

(I) Non-specific Disturbances of Health due to Vitamin Deficiency, and

(2) Endocrine Therapy.

Two special Discussions, amongst others, have also been arranged :-

I. Focal Sepsis in relation to Diseases of the Skin by the Sections of Dermatology, Laryngology, and Odontology. Thursday, 4th December, at 8 P.M., has been fixed as the date for the above. The Chair will be taken by Dr Graham Little, the President of the Section of Dermatology.

2. The Causes, Early Recognition, and Treatment of Non-tuberculous Meningitis by the Sections of Otology, Laryngology, Medicine and Neurology. The date of the Meeting is arranged for the Ioth December at 5.30 o'clock.

\section{THE SEMON LeCTURE, 1924 .}

The Semon Lecture will be delivered by Dr Jean Guisez of Paris in the Hall of the Royal Society of Medicine, I Wimpole Street, at 3 o'clock, on the afternoon of Thursday, 6th November. The chair will be occupied by Sir Wilmot Herringham, K.C.M.G., C.B.

The title of the Lecture is "Malignant Disease of the Esophagus."

\section{The Mitchell Lecture, I924.}

The Mitchell Lecture will be delivered by Sir St Clair Thomson, M.D., in the Hall of the Royal College of Physicians of London, Pall Mall East, at 5 o'clock, on the afternoon of Thursday, 6th November. Sir Humphry D. Kolleston, K.C.B., the President of the College, will preside.

The title of the Lecture is "Tuberculosis of the Larynx : its Significance to the Physician."

\section{Fellowship of Medicine and Post-Graduate Medical asscciation.}

During the Autumn Session a series of lectures upon Cancer will be delivered in the West Lecture Hall of the Royal Society of Medicine, at 5.30 P.M.

On Friday, 2Ist November, Mr H. S. Souttar will deal with "Carcinoma of the Esophagus," and on Wednesday, roth December, Mr James Berry will lecture upon "Cancer of the Thyroid Gland." 


\section{General Notes}

\section{POST-GRaduate InStRUCTION IN BORdeaux.}

Professor Agrégé Georges Portmann has organised a Post-Graduate Course in Oto-Rhino-Laryngology at the University of Bordeaux. The first course was held in June of this year and lasted for five weeks. It was attended by many American specialists.

The next course will commence on the roth July 1925 and will terminate on the 2oth August.

It is proposed to hold these courses each year during the months of July and August.

\section{King'S COLlege Hospital, London.}

Mr C. W. M. Hope, F.R.C.S., has been appointed Surgeon for Diseases of the Throat, and Lecturer on Laryngology and Rhinology.

Mr. V.E. Negus, M.S., has been appointed Demonstrator in Laryngology and Rhinology.

Dr Charles Goris, Member of the Royal Academy of Medicine, Belgium, and Officer of the Order of Leopold, a well-known member of the Specialty in Belgium, died at Ostend on the Ioth September. Dr Goris was born in February 1860.

\section{The American BoARd of Oto-Laryngology.}

The Committee appointed by the Section of Laryngology, Otology and Rhinology of the American Medical Association to consider a recommendation to establish a National Board for the conduct of Examinations in Oto-Laryngology and for the issuing of certificates to those deemed to be qualified to take up the practice of the specialty has now issued its report. Should it be considered favourably by the Section of the American Medical Association, the report will then come before the American Academy.

The object of establishing a Board is to elevate the practice of OtoLaryngology by determining standards of fitness for men engaging in practice and, further, for the issuing of certificates to those who qualify under the established standards. The certificate will be an assurance to the public that the possessor has had the proper preparation. Certain of the special Societies too, the American Otological Society, the American Laryngological Association, the American Laryngological, Otological and Rhinological Society, the American Academy of Ophthalmology and OtoLaryngology will require that all applicants for membership should possess the certificate. It is also proposed that the American College of Surgeons, on the recommendation of its Credential Committee, will admit the holder of this certificate without further examination.

The Board of Examiners will be known as the American Board of OtoLaryngology, and will consist of ten members, two from each of the Societies above mentioned, and two from the Section of Laryngology and Otology of the American Medical Association. Candidates for the examination and applicants for the certificate are divided into three classes: I. those who have practised Oto-Laryngology for ten years or 


\section{General Notes}

more; 2. those who have practised for five years and less than ten; 3 . those who have practised for less than five years.

Certain general requirements are demanded of all applicants, namely, high ethical and medical standing in their communities and the possession of a medical degree satisfactory to the Board. Special requirements are also asked for. Thus, men in classes $I$ and 2 who have already made a national reputation may receive the certificate of the Board without further proof of their efficiency, but those not thus qualified shall be required to furnish reports of ten cases observed and treated, and from these the Board will determine whether further examination will be necessary. Class 3 candidates must show proof of having satisfactorily completed for at least one year whole-time graduate work in Oto-Laryngology in an institution approved of by the Board, and, in addition, shall have devoted another full year to the specialty as a resident in a special clinic, or as an assistant to an established specialist or by taking graduate courses. As an alternative to the above preparation a member of class 3 may serve with a man of sufficiently high standing for a period of not less than three years. This may be accepted at the discretion of the Board.

When a special examination is regarded as necessary, it shall be practical and oral.

\section{The Treatment of Otitis Media in Fever Hospitals.}

It is both gratifying and instructive to observe the gradual but steady progress which is being made in providing the means of dealing more thoroughly with the prevention of chronic middle ear suppuration. This is exemplified in our present issue in which we publish two papers written by otologists attached officially to Fever Hospitals in two of our large centres, namely, in Birmingham and in Edinburgh.

The papers and the discussions which followed the reading of them in the Section of Otology of the Royal Society of Medicine and at the Scottish Society of Otology and Laryngology are deserving of careful consideration by our Public Health and Municipal Authorities. It is gratifying, however, to find that, at Newcastle-on-Tyne, the Fever Hospitals Medical Service Group of the Society of Medical Officers of Health discussed, in April of this year, the treatment of otitis media following infectious diseases, thus furnishing proof of the more widespread interest which is being taken in this field of preventive medicine. The benefits which accrue from the appointment of recognised otologists are not confined to the patients, because the hospital is saved considerable expense, as the period of detention of the patient is undoubtedly curtailed by reason of the specialised treatment.

\section{BOOK RECEIVED FOR REVIEW.}

Les Sourds-Muets; Etude Médicale pedagogique et sociale. By Dr G. de Parrel and Madame Georges Lamarque, The National Institute of Deaf-Mutes, Paris, with 162 figures, photographs and tables. Paris: Les Presses Universitaires de France, 49 Boulevard, Saint-Michel. 1925. Price 35 francs.

$$
676
$$


4TH EDITION. REVISED AND ENLARGED.

LEWIS'S PRACTICAL SERIES

\section{DISEASES OF THE NOSE AND THROAT}

By HERBERT TILLEY, B.S.(Lond.), F.R.C.S.(Eng.), Surgeon, Ear and Throat Department,

University College Hospital; Teacher of Laryngoiogy and Otology, Eniversiry of London. With numerous 111nstrations, ineluding 74 Plates. Demy 8vo.

28s. net. Postage 1s., abroad is. 3 d.

Extracts from Press Notices.

"The work is so comprehensive that it should be a valuable book of reference, whilst it is not too large to serve as an ordinary text.book."-Dritish Medical Journal.

"Wo have no hesitation in recommending his book to the practitioner as well as to the prospective specialist."- Lancet.

"The author is to be congratulated upon his work; as a text-book it is one of the best npon the snbject; . . . displays the master mind of an accomplished teacher."-Medical Press.

LONDON : H. K. LEWIS \& C0. LTD., 136 Gower Street, and 24 Gower Place, W.C. 1.

Telegrams : "Publicavit, Eusroad, London." Telephone: Museum 1072.

\section{INSTRUMENTS AND EQUHPMENT FOR \\ Examination of Ear, Nose and Throat, Operation on Tonsils, Adenoids, Mastoid, Nasal Septum}

\section{As supptied to and used in}

EAR, NOSE AND THROAT DEPARTMENT, ROYAI INEIRMARY, EDINBURGH THE EDINBURGH EYE, FAR AND THROAT INIIRMATY, ETC., ETO.

\section{ALSO THE CHEVALIER JACKSON INSTRUMENTS}

\section{ARCHD. YOUNG \& SON, 57-61 FORREST ROAD, EDINBURGH}

Surgical Instrument Makers to Royal Infirmary, Edinburgh

'Phone: Central 669.

Telegrams: "Bandage, Edinburgh," A.B.C. Code, 5th Ed.

\section{PILIING - INIXE CHEVALIER JACKSON INSTRUMENTS

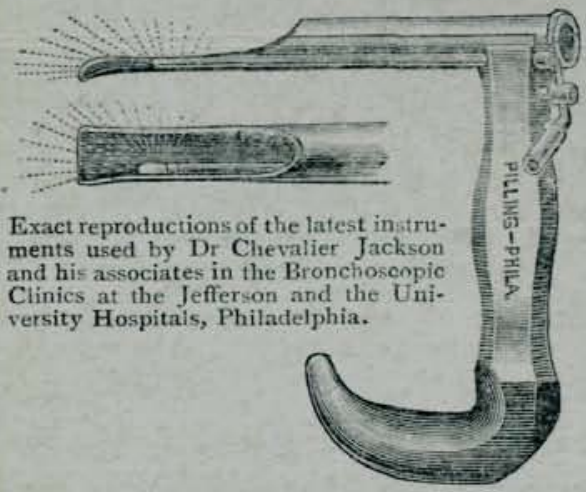 \\ Laryngoscopy, Bronchoscopy, Esophagoscopy, Gastroscopy, Pyloroscopy, Duodenoscopy, Retrograde Esophagoscopy, Pleuroscopy, etc.

$$
\text { and also for }
$$ \\ The Diagnosis and Treatment of Diseases of the Lungs, in- cluding Trachea and Larynx. \\ Catalogue on request \\ The George P.Pilling \& Son C0, N.E. Cor. Archand 23rd Streets, Philadelphia,Pa.,U.S.A.}



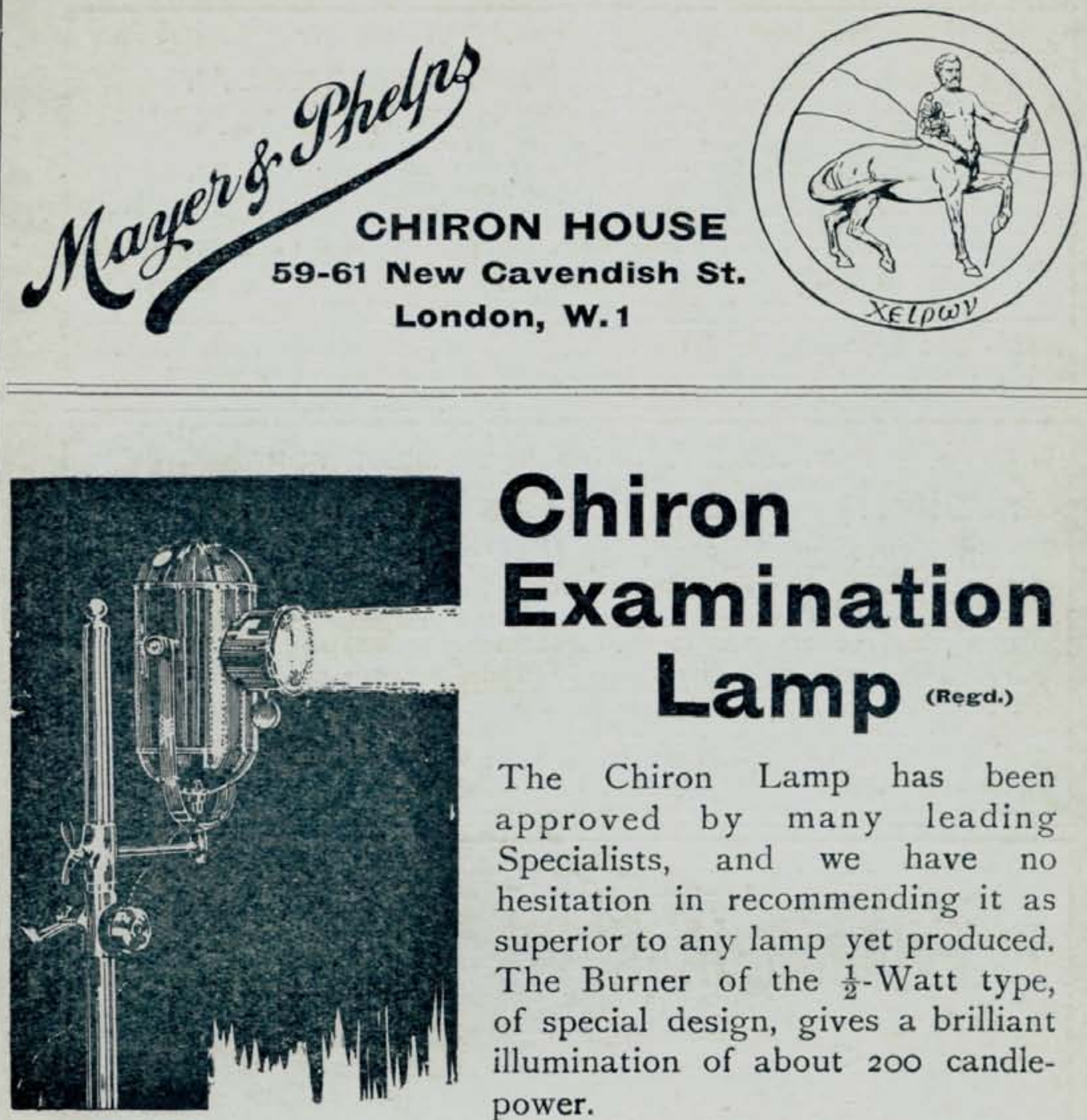

\section{Chiron Examination Lamp meras)}

The Chiron Lamp has been approved by many leading Specialists, and we have no hesitation in recommending it as superior to any lamp yet produced. The Burner of the $\frac{1}{2}$-Watt type, of special design, gives a brilliant illumination of about 200 candlepower.

\section{NEW CATALOGUE}

\section{The Chiron Armamentarium for the Peroral Endoscopist}

28 pages fully illustrated. Please write for a copy if you have not already received one. Sent post free to any part of the world. 